\title{
Türkiye’de Toplumsal Gelişmenin İki Formülü: Eğitimciliğin Tarihi ve Ekonomici Yaklaşımın Ortaya Çıkışı
}

\author{
The Two Formulas of Social Development in Turkey: The Occurrence of the \\ History of Educationalism and Economical Approach
}

\begin{abstract}
Burak SÖNMEZER*
Öz: Bu çalışmada, Türkiye'de, maarifçilik dediğimiz, toplumsal ve ekonomik gelişmenin ön şartı olarak eğitimi gören anlayışın bir tarihi olduğu gösterilmeye çalışılmaktadır. 19. yüzyılın başlarında ortaya çıkan bu anlayış, giderek Osmanlı Devleti’nin klasik çağındaki güçlü devlete dönüşün bir formülü olarak görülmeye başlanmıştır. Bu anlamda maarifçilik Osmanlı yönetici sınıfının tarihsel çıkarlarına göre şekillenmiş ve geleneksel aydınlar tarafından bütünüyle benimsenmiştir. Aynı dönemde iktidara sert eleştiriler yönelten ve meşrutiyet fikrini ortaya atan Jöntürkler de, geleneksel maarifçi fikirlerden kurtulmuş değildir. Jöntürkler tarafından da devam ettirilen maarifçi düşünceler ancak İttihat ve Terakki Cemiyeti’nin 20. yüzyıl başında Osmanlı burjuva sınıfıyla ilişki kurmasıyla birlikte değişmiş ve toplumsal gelişmeye ekonomici bir bakışa dönüşmüştür.
\end{abstract}

Anahtar sözcükler: Maarifçilik, Ekonomicilik, Toplumsal Gelişme, Aydınlar

Abstract: This study attempts to show the history of educationalism as the precondition for social and economic development in Turkey. Educationalism occurred at the beginning of the $19^{\text {th }}$ century in the Ottoman State. At that time it began to be seen as providing a major formula for the return to the powerful state of the Ottoman classical age. In this sense educationalism was accepted by the Ottoman traditional intellectuals, was shaped by the ruling class of the Ottoman State according to its historical interests. Although the Young Turks criticized government and suggested a constitutional monarchy, they did not depart from the traditional educationalist ideas until the beginning of the $20^{\text {th }}$ century. The educationalist's approach to social and economic development transformed into the economic approach with the establishment of the relation between Union and Progress as an organization of the Young Turks and the Ottoman bourgeoisie.

Keywords: Educationalism, Economic Approach, Social Development, Intellectuals

Bugün Türkiye'de toplumsal gelişmeye ilişkin söylemsel alanda maarifçiliğin (eğitimcilik) merkezi bir kavram olduğu kolaylıkla söylenebilir. Türkiye'nin en temel sorunlarına verilen yanitlardan, reklamlarda kullanılan esprilere kadar eğitim, anahtar bir kavram olarak kendini göstermektedir. Söz gelimi, ekonomik kalkınmanın eğitimle başarılabileceği konusunda toplumun her kesiminde yaygın bir inanç vardır. Ya da terör sorununun altında eğitim eksikliklerinin yattı̆̆ sık sık duyulan bir argümandır. Kadın sorununda, adli vakalarda, iş kazalarında fail hemen hemen istisnasız olarak eğitim eksikliğidir. Bu durum hem gündelik hayat içerisinde hem

\footnotetext{
* Öğr. Gör. Dr., Atılım Üniversitesi, İşletme Fakültesi, Halkla İlişkiler ve Reklamcıllk Bölümü, Ankara. burak.sonmezer@atilim.edu.tr
} 
de medya içeriklerinde eğitimin şart olduğuna yönelik ifadelerle devamlı pekiştirilmektedir.

Hiç kuşku yok ki, toplumsal gelişmeye ilişkin bütün problemlerin eğitimle giderilebileceğine yönelik yerleşik anlayışın bir tarihi vardır. Bu tarih Osmanlı Devleti'nin Batı karşısındaki askeri başarısızlıklarıyla birlikte başlar ve Batı'yı öğrenerek üstün olunabileceği kanaatinin gelişmesiyle pekişir. Bu bakımdan 18. yüzyıl son derece kritik bir dönemdir. Özellikle yüzyılın ortalarından itibaren Batıya "yeni usul"ü tetkik etmek üzere görevliler gönderilmiştir. Konuyla ilgili tetkikleri inceleyen Hanioğlu'na $(1985,14)$ göre artık "Osmanlı aydını benzeri bir eğitim sistemini imparatorluğa uygulamaktan başka bir çare olmadı̆ kanaatine varmıştır". Bu süreci birbiri ardına askeri okulların açılması takip eder. 1824'te ilkokul zorunlu hale getirilir. Aynı dönemde yurt dışına öğrenciler gönderilmeye ve eğitmenler getirilmeye başlanmıştır. (Akyüz 2015, 143-153).

Ancak bizim maarifçilik dediğimiz anlayışın ortaya çıkışının toplumsal güç ilişkileri bağlamında, başka kaynaklarının da olduğu açıktır. Bu anlamda maarifçilik belirli bir toplumsal kesimin verili koşullarda kendi genel ihtiyaçlarına ve çıkarlarına uyumlu biçimde toplumsal problemler için ürettiği ve topluma kabul ettirdiği çözümlerden başka bir şey değildir. Yukarıda da belirttiğimiz gibi yenileşme hareketlerinin cereyan ettiği Osmanlı'da 1800'lü yılların başında, "halkın cehaletini gidermek" (Cevdet Paşa 2008, 398) biçiminde ortaya çıkan bir anlayış olarak maarifçilik, II. Mahmut döneminde, farklı toplumsal güç odaklarının aleyhine, iktidarın merkezileşme çabalarıyla birlikte toplumsal ve ekonomik gelişmeye ilişkin anahtar bir kavram, bir ön koşul haline gelmiştir.

Öte yandan Osmanlı'da ekonomik gelişmenin doğurduğu farklı toplumsal kesimler, belirli bir gelişmişlik derecesine ulaştığında, toplumsal ve ekonomik gelişmeye ilişkin farklı fikirler üretmiş, özellikle 1900'lü yıllarla birlikte maarifçiliğe alternatif olarak iktisadiyatçı (ekonomici) bir yaklaşım öne çıkartılmıştır. Toplumsal gelişmeye ilişkin farklı projelerin gündeme gelmesi, bu fikirlerin üreticileri arasında toplumsal çelişkiler olduğunun da bir göstergesi sayılmalıdır. $\mathrm{Bu}$ anlamda söz konusu çelişki, yerleşik düzenin yönetici sınıfı ve onun kesimlerine ait geleneksel diye adlandırılabilecek fikirlerle, tarih ve politika sahnesine çıkmış yeni toplumsal sınıfa ait organik diye nitelendirilebilecek fikirler arasında yaşanmıştır.

$\mathrm{Bu}$ yazı maarifçi söylemin toplumsal/siyasal hayata nasıl girdiğine ve zamanla nasıl toplumsal gelişmeye ilişkin söylemsel alanın merkezi bir kavramı haline geldiğine yönelik tarihsel bir iz sürüm denemesi olduğu kadar, aynı zamanda söz konusu merkezi kavramın alternatifi olarak iktisadiyatçı bir düşüncenin ortaya çıkmasının mümkünlük koşullarını açıklamaya yöneliktir. Bunu yaparken Gramsci'nin aydınlar üzerine yaptığı teorik açılımlarda kullandığı organik aydın ve geleneksel aydın kategorilerine başvurularak, geleneksel ve organik fikirler ayrıştırılmaya çalışılacaktır.

\section{Maarifçiliği Ortaya Çıkartan Toplumsal Koşullar}

Tanzimat Fermanı Osmanlı Tarihi açısından son derece önemli bir sürece işaret etmektedir. Bir bakıma Osmanlı Devleti içindeki hakim Müslüman unsur ile tâbi konumdaki gayrimüslimlerin aralarındaki ilişkilerde eşitliğe doğru gidişte bir evre olarak değerlendirilen Tanzimat, diğer taraftan da Osmanlı modernleşmesinde ya da batılılaşmasında önemli bir adım olarak görülmektedir. Ancak bu süreç, farklı bir bakış açısıyla, Osmanlı merkez ve taşrasındayönetici sınıf kesimleri arasındaki mücadelelerin sonucunda ortaya çıkan sınıfsal bir uzlaşma olarak da değerlendirilmektedir (İnalcık 2006, 13-36).

Tanzimat'a giden sürecin erken dönemlerinde, 16. yüzyılın sonlarına doğru Osmanlı toplumsal düzeninin oturduğu iki temel kurum, kul ve tımar sistemleri bozulmaya başlamıştır 
(İnalcık 2003, 52). Kulluk sistemindeki bozulma, Osmanlı Devleti'nin, Avrupa'yla giriştiği savaşlarda ateşli silah kullanabilen güçlü birimlere olan ihtiyacın sonucu olarak ortaya çıkmıştır. Topraksız ve yurtlarını terk etmiş, ateşli silah kullanmakta maharetli gençlerin para karşılığ olarak ordunun özel birimlerinde görevlendirilmesi, zamanla bu birimlerin ordunun en etkili güçleri haline gelmesine neden olmuştur. Söz konusu gelişme, klasik Osmanlı düzeninde, kulların görev alanı olan hükümet ve askerlik işlerine, reayanın, yani vergi ödeyen, dolayısıyla üretim sektörünü oluşturan uyrukların sızması anlamına gelmektedir (Reyhan 2008, 125). Böylece iki temel sorun ortaya çıkmıştır; birincisi özellikle orduda geleneksel eğitim ve disiplin anlayış1 zaafa uğrarken, diğer taraftan vergi gelirlerinde de azalmalar olmuştur.

Köylü kitlelerin çeşitli nedenlerle hızla topraklarını terk etmeleriyle birlikte dejenerasyon tımar sistemine de yayılmıştır. Toplam tımar miktarında görülen azalmalar, bir taraftan, eskiden tımar olarak dağıtılan arazilerin saray erkanı elinde, özel mülk ya da vakıf arazisi olarak toplanmasına, öte taraftan Osmanlı ordusunda ve bölgesel idarede temel güç olan tımarlı sipahi sayısında büyük azalmalara neden olmuştur. Ancak esas sorun eskiden tımar olarak verilen arazilerden vergi toplama konusunda gündeme gelir. Sorunu aşmak için mültezimlik kurumunun oluşturulması ve beylerbeylerine silahlı ordu kurma ve vergi toplama hakkının verilmesi işleri iyice karıştırmıştır. Vergi gelirlerinde beklenen artış asla gerçekleşmemiştir. Tersine hızla çoğalan paralı askerler, hazineye daha fazla yük olmaya başlamış, en sonunda hazine paralı askerlere ödeme yapamayacak duruma gelmiştir. Celalî İsyanları diye bilinen hareketler, Sekban ve Sarıca adlı paralı askerî birimlerin uzun yıllar eşkıyalık yaparak tüm Anadolu'yu kargaşa ortamına sürüklemeleri tam bu sebeptendir (Faroqhi 2004, 563-566).

Osmanlı Devleti, on yıllarca süren bu ayaklanmaları bastırmak üzere taşradaki birimlere merkezden yeniçerileri birlikleri yerleştirme yoluna gitmiştir. Bu askerler, güçlerini Celalî âsilerine karşı kullanırken, mültezimlik de yaparak büyük servetlere ve geniş topraklara sahip olmuşlardır. Böylece daha önce toprakları işleyen köylü kitleleri ortakçı durumuna düşmüş; onlar ise taşranın yönetici sınıfları içerisindeki yerlerini almışlardır (Reyhan 2008, 111). Bu sürecin sonunda eyaletlerde bütünüyle hakim konuma gelecek olan ayan sınıfı ortaya çıkarken merkezi iktidarın gücü de azalmıştır (Pamuk 2005, 140-143). Sonuçta ayanlar, konumları gereği kaçınılmaz olarak hem taşrada devletin bir temsilcisi, hem de her kritik dönemde iktidar alternatifi durumuna gelmişlerdir (Reyhan 2008, 109).

Kuşkusuz Osmanlı merkezi idaresi yukarıda işaret ettiğimiz problemli durumun farkındaydı. Dönemin aydınlarına göre, bozulmanın nedeni asla Osmanlı geleneksel düzeni olamazdı. Devlet iktidarını hükümdarla özdeş gören bu anlayış, zayıf hükümdarların yetkilerini sarayda belli kişilere devrederek bu özdeşliği parçaladığını, iktidarı elde eden kişilerin de onu kendi çıkarları için kullandıklarını savunuyordu. Böylece bozulmanın temel nedeni olan rüşvet ve yolsuzluğun önü açılmıştı (İnalcık 2003, 52-53). Dolayısıyla, kurumların sağlamlığına güven tamdı; mesele güçlü bir hükümdar yokluğuydu. Aslında bir bakıma Celali isyanlarına neden olan bunalım ve daha da önemlisi isyanları bastırmak için seçilen yollar, tam da sözünü ettiğimiz anlayışa uygun olarak merkezi idarenin güçlendirilmesini amaçlamaktaydı. Ancak her tedbir Osmanlı merkezi idaresinin zayıflamasına ve taşrada yeni iktidar odaklarının güçlenmesine neden oldu.

Özellikle III. Selimle birlikte artık ayanla merkezi idare arasında açık bir savaş başlamıştı. II. Mahmut'un 1808 'de tahta çıkmasıyla, süregelen ayaklanmalar ve çatışmalar, geçici de olsa, belli bir sonuca bağlandı ve "imparatorluğun feodal teşkilâtının resmî bir ifadesi olan" Sened-i İttifak imzalandı (İnalcık 2004, 23-24; Tunaya 2004, 23). Sened-i İttifak, ayanın bağl1lı̆̆ına karşılık siyasal ve ekonomik durumlarının garanti altına alınmasından müteşekkil bir anlaşmadan başka bir şey değildi. Böylece III Selim'in sadık bir takipçisi olan II. Mahmut Dönemi 
göreli bir sükûnet sağlanarak başladı. Ancak bu durum geçiciydi. II. Mahmut kısa süre içinde, siyasi iktidarın tümünü, tıpkı Osmanlı klasik döneminde olduğu gibi, kendi üzerinde toplama amacını güden yeni bir reform dalgasına girişerek, öncelikle Anadolu'da, sonra da Rumeli'nde ayan takımının üzerine gitti (Lewis 2000, 90; Cevdet Paşa 2008, 151). Maksad1, yine klasik dönemin geleneksel siyasetine uygun biçimde, özellikle bölgesel iktidarı ele geçirerek, iktidara alternatif konuma gelen büyük ayan ailelerinin mülklerine el koymaktı (Jorga 2005, 198-201). Mahmut bunu büyük ölçüde başardı. İstanbul'u, devletin uzak bölgelerine bağlayan yolları güvenlik altına aldı. Bunun mânası, eskiden ayanın ekonomik ve siyasal olarak kontrol ettiği bölgelerde, artık merkezden gönderilen valilerin ve çeşitli kademelerde yüksek nitelikli görevlilerin sultan adına hüküm sürdürmeleriydi. Böylece hem merkezde hem de taşrada memur ihtiyacı hızla artmaya başladı (Tekeli 1993, 652).

II. Mahmut'un, ayanın bölgesel siyasal konumunu geriletmesi, Sened-i İttifak'ın yeniden resmi bir belgede revize edilmesinin yolunu açtı. Bu anlamda, Tanzimat Fermanı'nı, merkez ve taşradaki yönetici sınıf kesimleri arasındaki uzlaşmalar açısından, Sened-i İttifak'ın bir devamı olarak nitelendirmek hatalı olmayacaktır. Gerçekten de ayanın ortaya çıkmasında önemli bir faktör olan mültezimliği, "iltizamatusûl-ı mızırrası" diyerek mahkûm eden Tanzimat Fermanı, bu anlamda ayana darbe indirip geriletmiş, ancak mültezimler eliyle vergisi toplanan arazileri mültezimlerin hukuki mülkleri haline getirerek merkez ve taşradaki hâkim sınıf kesimleri arasında farklılaşan güç dengeleri sonucu ortaya çıkan yeni bir uzlaşmanın simgesi olmuştur (Quataert 2004, 974).

Öte yandan İnalcık'ın da belirttiği gibi, Tanzimat, toprak meselesini büyük köylü kitleleri lehinde çözmediğinden, esaslı bir inkılap olarak sayılamaz (2006, 25). Gerçekten de Tanzimatla birlikte reayanın durumunda herhangi bir değişiklik ortaya çıkmamıştır. Onlar hâlâ devlete vergi vermeye, ağa, bey ve Rumeli'nde çorbacı takımının kiracısı olmak nedeniyle onlara da ürünlerinin bir bölümünü bırakmaya ve baskı ve angaryalara muhatap olmaya devam etmişlerdir. Bu durum, reayanın taşrada mülk sahiplerine karşı ayaklanmalarına neden olmuştur. Özellikle Rumeli'nde ortaya çıkan ayaklanmalar ve bunların gittikçe ulusalcı karakterin ağır bastığı ayrılıkçı isyanlara dönüşmesi, romantik biçimde salt bir bağımsızlık kazanma isteğiyle değil, ama esas itibariyle, merkezdeki yönetici sınıfın müttefiki ve onun bir kesmi olan taşra hakim sınıflarıyla ezilen köylü kitleleri arasındaki mücadele olarak değerlendirilmelidir (Jorga 2005, 216).

\section{Tanzimat, Reformlar ve Maarif}

Tanzimat Fermanı'yla açılan dönem, ya da bütün bir reformlar çabasının "en temel özelliği yeniçeriler, ayanlar ve ulema gibi gruplar ve iktidar merkezlerinin zararına devletin merkezi gücünün arttırllması" olmuştur (Mardin 2000a, 130). Osmanlı merkezi idaresi, geleneksel toprak düzeninin bozulmasıyla ortaya çıkan merkezkaç kuvvetlerinin merkezi idarenin güçlendirilmesiyle, bir diğer deyişle, yönetici sınıfın taşradaki kesimlerinin siyasal güçlerini kırarak giderilebileceğini düşünmektedir. Ancak bu amacı gerçekleştirmek için sadece askeri güç kullanmak yeterli değildir. Bunun için daha önceden büyük oranda taşradaki yönetici sınıf kesimlerinin denetiminde olan hizmetlerin bütünüyle merkezin kontrolü altına alınması gerekmiştir. Başka deyişle, taşrada hakim sınıf kesimlerin arasındaki güç dengelerinin değişmesi, devletin işleyişinin bütünüyle değiştirilmesini beraberinde getirmiştir (Toprak 1992, 198). II. Mahmut işleyişi öncelikle kendisinden ve sadrazamdan başlayarak değiştirmiştir (Jorga 2005, 202). Artık sadrazam ve paşalar değil, merkezi devletin çalışanları söz konusudur. Devletin çeşitli kademelerinde çalışan memurlar belirli bir ücret karşılığında görev yapmaya başlamışlardır. Bürokrat; "nezaretlerin, kuruluşların ve vilayet örgütlerinin kaydlhayatla istihdam edilen, terfi, tayin, taltif ve cezalandırllması belirli kurallara bağll, hiyerarşide yeri olan bir kişidir" 
(Toprak 1992, 198; Ortaylı 2006a, 144). Maliye alanında yapılan düzenlemelerle vergi toplama işi de doğrudan devlet memurları tarafından yürütülmeye başlanmıştır (Jorga 2005, 359). Bu uygulama kuşku yok ki, vergi mükellefiyle devlet arasında aracılık yaparak servet ve güç elde eden ayan ve mültezim takımına en büyük darbeyi vurmuştur.

Aynı şekilde, özellikle II. Mahmut Dönemi'nde yeni bir kavram olarak ortaya çıkan "maarif" köklü bir yenilik olarak belirmiştir. "Din ve Dünya için gerekli din bilgilerini ve yararl bilgileri (fen) yaymak ve halk arasında cahilliği kaldırmak" (Berkes 2003, 229-230) olarak anlaşılan maarif, ulema tarafından sadece dinî hislerden dolayı gönüllü olarak yapılan ve bağışlarla ayakta duran bir faaliyet olmaktan çıkartılarak, Avrupa tarzında ücretli memur haline getirilen öğretmenler tarafindan icra edilen bir iş haline getirilmiştir. Öğretmenleri kontrol eden bir komisyonun kurulması ve eğitim işinin merkezin denetimine alınması da ihmal edilmemiştir (Jorga 2005, 358). Yeni okullardan oluşacak bir eğitim yapısının üniversiteyle taçlandırılması da ilk kez bu dönemde düşünülmüştür. Zaten devlet yönetiminin her alanında ortaya çıkan büyük yenilikler, kendiliğinden ciddi bir eğitim hamlesini de gerektirmektedir. II. Abdülhamit döneminde Sait Paşa'nın kaleme aldığı bir layîhada, devletin iç ve dış işlerinin hakkıyla yürütülmesinin, adaletin sağlanmasının, ordunun idaresinin ve bütün maliye işlerinin yürütülmesinin temel şartının maarif olduğu belirtilmektedir. Sait Paşa, "servet ve saadet-i ammeye hizmet eden kâffe-i tesisat ve ameliyat maarif münteşir olmadıça vücuda gelmez" demekte, ayrıca, "zihinleri eğitimle açılmış olan Hıristiyan halkların kontrol altında tutulması" için de eğitimin zorunluluğunu vurgulamaktadır (Lewis 2000, 178-179).

Belirttiğimiz gibi Osmanlı Devleti'ndeki merkezileşme çabaları İstanbul'da yeni bir yönetici aydın tabakanın oluşmasına neden olmuştur. Bu yeni bürokratlar, kendilerinden önceki yönetici aydın kadrolar gibi devlet iktidarıyla sultan arasındaki özdeşliği hiçbir şekilde sorgulamamaktadır. Tanzimatla birlikte can ve mal güvenlikleri sağlanmış olmasına karşın hâlâ bulundukları pozisyonların biricik nedeni sultan ve onun iktidarından başka bir şey değildir. Bununla birlikte yeni yönetici aydın zümresi geleneksel Osmanlı düzeninin artık değişmesi gerektiğini, aksi takdirde İmparatorluğun bir arada tutulamayacağının bilincindedir. Ancak buradaki kritik nokta, söz konusu zümrenin düzen problemini padişahın çevresini saran, onu yönlendiren, dış dünyadan habersiz, eski kafalı ve tutucu bürokratlarda görmeleridir. Padişahı yönlendiren bu geleneksel kadroların temizlenmesi yönündeki fikri eğilim gitgide radikalleşerek padişahın danışacağı bir parlamento fikrine kadar varacaktır. Bu yeni tip yönetici aydın, Klasik Osmanlı bürokrasisi gibi ordu ya da ulema içinden yetişmemektedir. Onların yetiştiği yerler artık modern okullar; devlet yönetimini öğrendiği yerler ise Tercüme Odası ve elçilik kâtiplikleridir.

Tanzimat paşaları diye bilinen Fuat, Âli ve özellikle Reşit paşalarla birlikte Tanzimat memuru ya da Tanzimat adamı diyebileceğimiz yeni tip yönetici aydınların (bk. Ortaylı 2006b, 315) bürokraside egemen olmaları, doğal olarak beraberinde Tanzimat öncesine nazaran farklı bir zihinsel durumun egemenliği anlamına da gelmiştir. Bundan böyle, Osmanlının geri kalmışlığı kabul edilmekte ve Batı'ya nasıl yetişilebileceği üzerine kafa yorulmaktadır. Bu yeni aydın tipi, maarif, ziraat ve sanayi üzerinde durmaktadır. Özellikle ilgili nezaretlerde encümenler, maarif planları ve ziraattaki çöküş üzerine çalışırlar. Tabii bu zihinsel değişim günlük hayatı da değiştirmiştir. Yeni yönetici aydın kesimin ön ayak olduğu yeni hayat tarzı kendisini, İstanbul'da ve büyük liman kentlerinde büyük konaklar, Avrupa'dan getirtilmiş mobilyalar ve genel olarak bir alafrangalıkla beraber lüks düşkünlüğü biçiminde gösterir (Göçek 1999, 89-99). Fakat bunlardan çok daha önemli olarak, kadınların eğitim görmesi, bir okuma alışkanlığının gelişmesi ve roman başta olmak üzere çeşitli çeviriler üzerine ilginin doğması bu çevreler içinde yoğun olarak gözlemlenir (Berkes 2003, 314). Hiç kuşku yok ki bahsedilen çevreler içinde sınırlı kalsa 
da, "halkın yalnız hafiz, vaiz, hoca ve padişah buyruğu dinlediği bir zamanda, din ve siyasa dışı, çekici ve eğlendirici şeylere düşkünlüğünün başlamast, devrimsel bir olay”dır (Berkes 2003, 369).

\section{Layîhacı Jöntürkler}

Reformlar çağının ürünü olarak Jöntürkler'in kökenini 1865 yılında kurulan İttifak-1 Hamiyyet'e, oradan da Şinâsi ve Mustafa Fazıl Paşa'ya dayandırmak doğru olacaktır (Mardin 1998, 19-20). Osmanlı Devlet idaresinde radikal reformlar öneren bu örgütün bütünüyle geleneksel fikirlerle hareket ettiğini ileri sürmek gerçekten de ilginç bir paradoksa işaret etmektedir. Diğer bir deyişle, öncülleriyle birlikte Jöntürkler, toplumsal gelişmeyi sağlamak ve Avrupa'yı yakalamak konusunda II. Mahmut'tan beri süregelen, zamanın geleneksel kavrayışı içerisindeki merkezi kavramlarla düşünmüşler ve hareket etmişlerdir. Bu hiç değilse iki yönden böyledir. Birincisi, İttifak-1 Hamiyyet'le başlayan hareketin esas hedefi sultanlar ve monarşi değildir. Şinâsi'nin yazılarındaki dikkat çekici vurgu rejimin aynen muhafazasına yöneliktir. Mustafa Fazıl Paşa ise devlet idaresinde yapılması gereken radikal reformları hâlâ Padişah'tan beklemekte ve bu yöndeki önerilerini 1867 'de yurt dışından yazdığı meşhur mektupta dile getirirken Abdülaziz'e “Efendimiz” diye hitap etmektedir (Mardin 1998, 308). Onlar da, muhalifi oldukları Tanzimatç1 paşalar gibi, hem reformculardır, hem de padişahın etrafını saran bürokratlardan şikayetçi; bu yüzdenBab-1 Âlî’yi ve özellikle Âli ve Fuat paşaları hedef almışlardır.

Şinâsi ve Mustafa Fazıl'ın geleneksel görüşlerinin ikinci göstergesi toplumsal gelişmenin ön şartını maarifte görmeleridir. Şinasi, yeterli bir toplumsal gelişmenin olmadığını gerekçe göstererek siyasal rejimde bir değişiklik fikrine şiddetle karşı çıkmıştır. Ona göre yaşadıkları devir bir "öğretme devri" olmalıdır; II. Mahmut Dönemi’nden beri Avrupa'ya eğitim için gidenlerin yurda dönüp halkı aydınlatmaları gerekmektedir. Şinâsi yurt dışına çıkmadan önce sadece meşhur Tasfir-i Efkâr'ı çıkartarak ilk kez maarif meselesi hakkında yazılar yazmamıştır; o aynı zamanda fikirlerini uygulayabileceği bir konumda, Meclis-i Maarif üyeliği de yapmaktadır. Mustafa Fazıl Paşa ise "Efendimiz" diye başladığı mektubunda, hiç kimsenin, "modern Avrupa devletlerinin üstünlüğ̈̈nün, yeterli sayıda 'aydın ve eğitimli' insanın varlığına dayalı olduğunu" inkâr edemeyeceğini ileri sürmüştür (Mardin 1998, 310).

Sultana layîhalar vasıtasıyla reform önerileri sunmak en azından 1900'lerin başlarına kadarki Jöntürk hareketinin en temel özelliklerinden biridir. Bu durum onların tek muhataplarının sultan olduğunu göstermesi bakımından önemlidir. İttifak-1 Hamiyyet kurucularından ve Jöntürk hareketinin önemli isimlerinden Namık Kemal sultan tarafından Kıbrıs'a sürüldüğünde bile ona layîhalar yazmaktan vazgeçmemiştir. Kafasındaki düşünce hâlâ Sultan'ın iyi, fakat çevresinin, yani Bab-1 Âlî bürokratlarının kötü olduklarına dair geleneksel düşünceden başka bir şey değildir. Tıpkı Mustafa Fazıl Paşa gibi Namık Kemal de Avrupa'nın tüm ileriliklerini maarife bağlamaktadır: "Avrupa'da maarifin mertebe-i terakkisini ... kullandiğımız saat, denizde gezdiğimiz vapurlar, tramvaylar, demiryollar gösteriyor" demektedir (Namık Kemal 2005, 110). O da Şinasi'yi takip ederek bilginin bütün insanlar tarafından anlaşılabileceği yönündeki anlayışın sıkı bir takipçisidir (Gündüz 2016, 109).

Bir bütün olarak aydınların kafalarındaki bu fikirlere karşın eğitim kurumları devletin gereksinim duyduğu sivil ve askeri bürokrasiyi yetiştirmekten başka işe yaramamaktadır. Kuşkusuz okullarda sivil alanın, bir diğer deyişle, tarımın, sanayinin ve ticaretin ihtiyaçları doğrultusunda eğitim verilmesi düşünülmektedir; hatta bu amaçla 1840'lı yıllardan itibaren, sayıları giderek artan, ziraat ve sanayi okulları açılmıştır. Ancak sonuç asla beklendiği gibi olmamıştır. Örneğin 1847'de İstanbul'da kurulan Amelî Ziraat Mektebi kısa sürede kapanmıştır. 1864'te kurulan Mekteb-i Sanayi de aynı akıbeti paylaşmış, Mithat Paşa'nın Rusçuk ve Niş’teki girişimleri de 
yaygınlaşamayarak güdük kalmaktan öteye gidememiştir. Yurt çapında endüstrinin ihmal edilebilir düzeyi okulların işlevsiz kalmasının esas nedenini oluşturmaktadır. Kimi aydınlar bunun farkına varsalar da, yine maarifçi fikriyattan hareketle, bu kez, okullarda şahsi teşebbüs fikrini aşılayacak programlar geliştirmek gibi garip bir yola girmişlerdir (Tekeli 1993, 656-657).

Osmanlı Devleti'nde oldukça geniş bir aydın tabakasını oluşturan Jöntürkler'in tüm bu fikirlerinin ve önerilerinin kaynağı Batı'dır. Çoğu Batı ülkelerindeki toplumsal gelişmeleri yerinde görmüş, Batı'nın eğitim kurumlarını tetkik etmiştir. Bu tecrübelerinden yola çıkarak kendi yurtlarında toplumsal gelişmenin şartını hızlı ve yaygın bir eğitim seferberliğine bağlamışlardır. Halbuki bu bir yanılgıdır. Akyüz'ün de $(2016,160)$ çok yerinde tespit ettiği gibi "19. yüzyılın ortalarına kadar Fransa, İngiltere ve Almanya gibi ülkelerde ilkögretim geriydi ve cehalet yaygındi. Bu ülkelerde bilimsel ve teknik gelişmeler genel eğitimin yaygınlaşmasından önce ortaya çıkmıştı”.

\section{Abdülhamit ve Reformlar}

Tanzimat Fermanı'yla gelişen merkezileşme ve Batı kurumlarının memlekete yerleştirilmesi çabasının en üst noktasını II. Abdülhamit dönemi oluşturur. Ancak II. Abdülhamit dönemi Osmanlı devlet yapısında farklı bir merkeziyetçi anlayışı da temsil etmektedir. Tanzimat'tan beri devam eden merkezileşme çabaları, gittikçe Osmanlı bürokrasisini, özellikle Batı'yla ilişkilerinin sağladığ güçlü konumlarıyla, neredeyse padişahların üzerinde bir iktidar sahibi düzeye getirmiştir. Üstelik, imparatorluğun bir çok bölgesinden haberdar olan radikal bir Batı yanlısı Mithat Paşa'nın, anayasacı fikirlerle padişahları tahtan indirmesi ve meşrutiyet denemesi, merkezdeki yönetici sınıfın ve geleneksel iktidarın konumunu sarsan bir nitelik kazanmıştır. Mithat Paşa ve anayasacı meşrutiyetçiliğin yenilgisi, iktidarın daha da merkezileşerek doğrudan II. Abdülhamit'in tepesinde bulunduğu, muhafazakâr diye nitelendirilebilecek bir yönetici kadronun eline geçmesine yol açmıştır. II. Abdülhamit rejimi imparatorluğun parçalanmasını ancak böyle bir bask1 rejimiyle engelleyebileceğini düşünmekte, dolayısıyla, merkezin gücünün kısıtlanması anlamına gelen meşrutiyet ve anayasacılığa bütünüyle karşı çıkmaktadır.

II. Abdülhamit, Tanzimatçı paşaların önayak olmasıyla, geçmişinde uzunca bir Avrupa seyahatine de çıkmıştır. Gezdiği yerlerde gördükleri onu sadece hayran bırakmamış, aynı zamanda Osmanlı Devleti'yle Avrupa arasındaki farkı da anlamasına neden olmuştur (Georgeon 2006, 36-46). Avrupa'da katıldığı fuarlarda ve gezdiği kentlerde sanayi üretiminin boyutlarıyla tanışmış, ticaretteki ilerlemeleri görmüştür. Onun merkeziyetçi ve muhafazakâr olduğu kadar 1slahatç1 yapan önemli bir faktör belki de tam bu tecrübedir. Ancak bu tecrübelerle yoğurduğu 1slahatçı fikirleri, onun kafasında baş aşağı durmaktadır. Tıpkı kendinden öncekiler gibi eğitimle toplumsal gelişme arasında kurduğu ilişki ters dönmüştür. Sait Paşa tarafından da sıklıkla belirtildiği gibi maarifin esas gayesi sanayi ve ticarete yönelik pratik bilgilerin öğrencilere aktarılmasıdır. Abdülhamit bu yolla Osmanlı Devleti'nin şaşaalı dönemlerine dönmeyi ummaktadır. Gaye, sadece askerlik, tıp, hukuk ya da haberleşme gibi alanlarda ihtiyaç duyulan eğitimli personeli yetiştirmek değildir; bunun çok ötesinde, toplumsal bir gelişmenin ön şartı eğitim olarak görülmektedir. Okullarda eğitilen Müslümanlar hem memleketi geliştirecek, refahı sağlayacak, hem de Osmanlı Hanedanı'na ve Hilafet kurumuna içtenlikle bağlanacak, bu yolla devlet hızla güçlenecektir. Böylece II. Abdülhamit Tanzimat'tan beri sorulan "bu devlet nasıl kurtulur" sorusuna geleneksel cevabı da vermiştir: Bu devlet her şeye hâkim güçlü bir hükümdarla kurtulacaktır. Dedesi II. Mahmut'u kendisine örnek almıştır (Georgeon 2006, 46).

II. Abdülhamit'in maarifi geliştirmek amacıyla giriştiği büyük çaba aslında takdire şayandır. Maarifteki bu ilerleme öyle bir boyuttadır ki, sadece maarif için, örneğin aşar vergisinde artışlara 
gidilmiş, hatta özel bir maarif vergisi bile çıkartılmıştır. Yapılan yeni okullar, maarifin devlet katındaki ayrıcalıklılığının belirtisi olarak son derece gösterişlidir; mimarilerine özel ihtimam gösterilmiş, yurt dışından mimarlar getirtilmiştir. Abdülhamit'in adı "Maarifperver"e çıkmıştır (Georgeon 2006, 290-291). Ancak bu çabalar II. Abdülhamit'in beklemediği sonuçları da ortaya çıkartmıştır. Batı'dan gelen hürriyetçi fikirler maarif yoluyla memlekete girmekle kalmamış, okullar muhalefet mekânları haline gelmiştir (Hanioğlu 1985, 46).

\section{Layîhacılıktan İhtilâlciliğe; Maarifçilikten İktisadiyatçılığa Jöntürkler}

Abdülhamit rejimi, muhalefet odakları haline gelmeleri nedeniyle okullarda baskıları arttırdıkça Jöntürk muhalefetinin gücünün sıçramalı bir şekilde arttığı söylenebilir. 1860'lı yılların ikinci yarısından itibaren tırmanışa geçen Jöntürk muhalefeti, İslâmî meşveret anlayışına dayanarak sultanın çevresini saran bürokratların yerine bir meclis fikrini öne çıkartır (Petrosyan 1974, 126127). Hâlâ geleneksel fikirlerden kopamayan bu aydınların ülkenin nasıl kurtulacağına ilişkin düşünceleri Tanzimat memurununkilerden ya da II. Abdülhamit'ten hiç de farklı değildir. Fransız İhtilâli'nin 100. yıl dönümünde kurulan İttihat ve Terakki Cemiyeti'nin önemli liderlerinden Murat bile Sultanla yaptığı bir görüşmenin ardından "Hünkârımız bir melek" diyerek yazılar yazabilmiştir (Georgeon 2006, 160). Murat, önemli Jöntürk gazetelerinden Mizan'1 çıkartmaktadır. II. Abdülhamit'le görüşmesinden sonra İttihat ve Terakki'de gözden düşmesine karşın örgütün ve Jöntürk Hareketi'nin diğer bir önemli lideri ve Meşveret gazetesinin sahibi Ahmet Rıza'yla birçok konuda ortak görüşlere sahiptir. Her ikisi de Osmanlı Devleti'nde reformların gerçekleşmesinin mümkün olmadığını düşünmektedir. Bu durumun nedenini bir iktidar problemi olarak görmeyen İttihat Terakki liderleri, toplumda eğitim seviyesinin yükseltilmesinin gerekliliğini savunurlar (Mardin 2000b, 98, 192). Ahmet Rıza açıkça, ülkenin kurtulması için ziraat ve sanayinin geliştirilmesini önerir ama bunun ön şartını eğitim düzeyinin yükseltilmesi olarak koyar (Mardin 2000b, 182). Jöntürkler içinde düşünsel olarak farklı bir kutbu temsil eden Prens Sabahattin bakımından da durum farklı değildir. Meşhur Bu Memleket Nasıl Kurtarılabilir başlıklı broşürde "ülke'de bireyci eğitimde bulunacak okullar açmak, gençleri anglo-saxon eğitim çerçevesine sokmak" gerektiğini savunmaktadır (Prens Sabahattin 1965, 59-60). Kısacas1, Jöntürk önderlerinin tümünün bu dönemki fikirleri tıpkı II. Abdülhamit’in maarife ilişkin fikirleri gibi baş aşağı durmaktadır.

Ahmet Rıza'nın kişisel yaşam öyküsü, Jöntürklerin maarif konusundaki tutumları bakımından dikkate değerdir: Fransa'da ziraat öğrenimi görmüştür. Yurda döndügünde yeni tarım tekniklerini uygulamak için işe koyulduysa da, ironik biçimde yeterli sermayeyi bulamadığından bu girişiminden vazgeçmiştir. Çiftçiler ise, ona göre, cahilliklerinden yeni tekniklerin önemini kavrayamamaktadır. Böyle bir tecrübe Ahmet Rıza'da maarifçi eğilimlerin güçlenmesiyle sonuçlanır. Artık toplumu maarif yoluyla uyandırmaya girişir. Bursa'da Maarif Müdürlüğü’ne kadar yükselir. Daha sonra Avrupa'daki ilerlemeleri yakından incelemek için tekrar gittiği Fransa'da Pozitivizmle tanışarak, bir maarif programı geliştirmek için çalışır ve bunları lâyihalar yazarak II. Abdülhamit'e iletir. Ancak yazdıklarının dikkate alınmadığını görünce, tezlerini duyurmak için Meşveret gazetesini çıkartmaya başlar (Kuran 1945, 27). Meşveret'te de baş aşağı duran toplumsal gelişme perspektifinde bir değişme yoktur. Gazetenin daha ilk say1sında "İlim ve maarif sayesinde" hürriyete ve medeniyete ulaşılacağı, Avrupa'nın da "kemale maarifle yükseldiği" belirtilmektedir (Coşkun 2006, 51, 70, 413).

Jöntürk Hareketi'nin siyasal örgütlenmesi olarak İttihat ve Terakki Cemiyeti'ndeki gelişmeler de önemlidir. 1900'lü yılların başlarına kadar cemiyetin temel faaliyeti olan yurt dışından çeşitli yayınlarla memleketi etkileme stratejisiyle bir yere ulaşılamayacağı anlaşıldığında, “dâhilde” örgüt kurmaya girişilmiştir (Kuran 1945, 196-199; 1956, 377). İttihat Terakki Cemiyeti 
memleketin kurtulması için öncelikli olarak dış müdahalelere karşı harekete geçilmesini gündeme getirdiğinden, söz konusu müdahalelere en açık bölge olan Makedonya'da güçlenir. Osmanlı topraklarının siyasi olarak en karışık bu bölgesi son derece özeldir. Bir kere ekonomik olarak en gelişmiştir. Liman kentlerinden, özellikle ihracat merkezi niteliğindeki Selanik’ten iç bölgelere ağaç dalı şeklinde uzanan demir yolları, bu bölgede ticaretin kapitalistleşmesine ve toprağın kapitalist piyasanın gerekliliklerine uygun olarak kullanılmasına neden olmuştur (Toprak 1992, 210; Tekeli \& İlkin 2003, 25). Dolayısıyla bu bölge, ekonomik ve politik talepler ileri sürebilen iyice güçlenmiş bir burjuva sınıfını barındırmaktadır (Pamuk 2005, 214). Osmanlı Devleti'nde 1800'lü yıllarda ortaya çıkan bu yeni toplumsal sınıf, Makedonya'da toplumun aydın kesimini oluşturan subay ve bürokratlarla oldukça yoğun ilişkiler içindedir. "Bunların misafir odaları Genç Türklere daimî surette açıktır". Ayrıca İstanbul'daki şiddetli baskıdan kaçan İttihatçıların sığınağı yine bu evlerdir (Temo 2000, 99). Sadece bu kadarla kalmaz, bu bölgedeki tüccar yazıhaneleri İttihat ve Terakki Cemiyeti'nin örgütlendiği, İstanbul'a gönderilen örgüt yayınlarının depolandığı yerlerdir (Kuran 1956, 368).

XIX. yüzyılın ikinci yarısından beri özgürlükçü fikirlerin kaynaklandığı ordu ve bürokrasi, Makedonya'da iktisadi gelişmenin ortaya çıkardığı yeni sınıfla, yani bu evlerin ve yazıhanelerin sahipleri olan tüccarlarla organik olarak ilişkiye geçmiştir. Uzun bir süredir Avrupalılaşmak zorunda kalan ordu, ülkenin esas eğitim görmüş kitlesini barındırmaktadır. Ülke içindeki endüstrileşmenin önemsizliği, dolayısıyla kent kültürünün düşük gelişme düzeyi, eğitimlilere ve Türk entelijensiyasına subay ve memur olmaktan başka seçenek bırakmamıştır. Kısacası toplumun aydın kesimi ordu ve bürokrasi kademelerinde yoğunlaşmıştır (Troçki 1995, 14-15). Tüm bunlara ek olarak, subaylar, ayrılıkçı hareketlerle aktif mücadele içinde bir taraftan bölgeyi çok iyi tanıma fırsatı bulmuşlar, hem de orduda verilen eğitimler sayesinde milliyetçilik hareketleri konusunda ciddi bir bilgi birikimi edinmişlerdir (Tekeli \& İlkin 2003, 49-50). İttihat ve Terakki Cemiyeti'nin Makedonya'daki faaliyetleri arttıkça bu durumun sonuçları da ortaya çıkmaya başlamıştır. Çeşitli merkezlerde yeni şubeler açılmış, subay ve bürokratların başını çektiği küçük gruplar ortaya çıkmış, Jöntürk yayınlarına ve özellikle cemiyetin yayın organı niteliğindeki Şura-yı Millet gazetesine ilgi büyümüştür.

Makedonya'da, cemiyet teşkilatını yaygınlaştırdıkça örgütlediği toplumsal kesimlerin etkileri de gözle görülür olmuştur. Söz konusu etkinin ilk ve en önemli göstergesi herhalde maarifçi bir düşünceden, iktisadiyatçı bir bakışa dönülmesidir. Maarifçi olan Jöntürkler, artık maarifle iktisat arasında o güne kadar hiç kuramadıkları bir ilişkinin farkına varmışlardır. Keskin ifadeleriyle bilinen ve bu yüzden kendi düşünceleriyle cemiyetin fikirleri arasında hep bir açı bulunan Abdullah Cevdet "ilimsiz para kazanmak ve parasız ilim kazanmak mümkün değildir" diyerek, gazetesinde okuyucularına "ilim ve para kazanın" diye seslenmektedir. "Para"dan iktisadi gelişmeyi anlayan Abdullah Cevdet, para ve ilim olmadan "istihsal ve muhafaza-i hürriyet-ü hukuk mümkün değildir” demektedir (Mardin 2000b, 247). Ahmet Rıza ise artık Cemiyetin en önemli fikrî lideri haline gelmiş, çıkarttığı Meşveret'i kapatmış ve Cemiyetin resmi yayını Şuray-ylMillet'in başına geçmiştir. Ticareti “milletin cismaniyeti” olarak ilan eden gazetede Ahmet Rıza, "Alem-i iktisat nokta-i nazarından hayat bir metaya teşbih edilirse onun klymeti, değeri sa'ydır" diye yazmaktadır (Mardin 2000b, 257-258). 1908 Devrimi'nden sonra uzunca bir süre Meşrutiyet ekonomisini idare edecek olan Cavit Bey'in yazıları da İttihat ve Terakki Cemiyeti'nin fikri olarak geldiği noktayı göstermesi bakımından önemlidir. Cavit Bey Avrupa devletlerinin nasıl ilerlediğini irdelediği yazılarından birinde, Avrupalı aydınların "bir devletin siyasi olarak güçlenmesi ve gelişmesinin ekonomik güçlenme ve gelişimine bağlı olduğunu" anlamış olduklarını belirtmektedir (Çavdar 1992, 142). 
Kuşkusuz bu dönüşümün bir sebebi, Batı'dan gelen inanılmaz ekonomik baskılara bir tepki olsa da, esas faktör cemiyetin Makedonya'da ve giderek tüm imparatorlukta dayandığı sosyal sınıflar olmalıdır. 1902'den sonra gittikçe ön plana çıkan “Hürriyet, Müsavat, Uhuvvet” söylemini de cemiyetin dayandığ 1 sınıflar bakımından değerlendirmek gerekmektedir. Bu söylem hiç kuşkusuz "bu devlet nasıl kurtulur" sorusuna verilen bir cevap olarak, özellikle Makedonya'da iktisadî olarak baskın olan tüccar sınıfına aittir. Böylece geleneksel fikirlerden sıyrılan Jöntürkler toplumsal gelişmeyle maarif arasında kurdukları ilişkiyi de ayakları üzerine yerleştirmişlerdir.

Genel olarak Jöntürk Hareketi’ndeki dönüşüm bunlarla da sınırlı değildir. Dâhilde hızlı bir örgütlenmeye giden İttihat ve Terakki Cemiyeti, iktisadiyatçı bir düşünceyi gündeme getirirken, ekonomik gelişmenin önündeki engeli de netleştirmiştir. 1800'lü yılların sonlarında toplumsal ve ekonomik gelişmenin önündeki engelin, geleneksel biçimde, eğitim eksikliği olduğunu düşünerek maarifçi ve tabî uysal bir siyasal hat izleyen Jöntürkler, 1902 yılına gelindiğinde ekonomik gelişmenin önünü tıkayan esas faktörün mutlakıyet olduğunu ilan etmektedir. Böylece cemiyet, toplumsal gelişme sorunuyla siyasal rejim sorununu da özdeşleştirerek geçmişten bütünüyle farklı bir perspektifi gündeme getirmiştir. "İttihat ve Terakki Cemiyeti" artık, "kötü durumun kaynağını şimdiki yönetim biçiminin yanlışlık ve eksikliklerinde değil de, kumandanlar, denetmenler, valiler, seraskerler ve vezirler gibi yönetici kişilerin ...kötü kişiler olmasında arayan tüm görüşlere karşı çıkarak, bunları engellemektedir" (Petrosyan 1974, 304) "Devrimci bir değişim" öngören cemiyetin metodu açıktır: "Silah ile mukavemet, tatili iştigalât ile silahsız mukavemet, Hükûmeti hazıraya vergi vermemek... Kıyamı umumî...” (Kuran 1945, 242). Bu ihtilal demektir.

\section{Sonuç}

Toplumsal gelişmeye ilişkin bütün problemlerin eğitimle aşılabileceği yönündeki anlayış, bugün bize evrensel bir doğru gibi görünse de bu anlayışın bir tarihi vardır. Askeri alanda başarısızlıklarla birlikte Osmanlı merkez ve taşrasının hâkim sınıfları arasında gelişen mücadelelerin bir sonucu olarak maarif kavramı, başta, askeri bir zorunluluk ve merkezi otoritenin taşraya hükmetmesinde bir gereklilik olarak ortaya çıkmış, gitgide, özellikle II. Mahmut döneminden itibaren toplumsal ve ekonomik gelişmenin bir anahtarı olarak sunulmaya başlanmıştır. Zamanla toplumsal gelişmeye ilişkin geleneksel söylemsel alanın merkezi kavramlarından biri haline gelen maarifçilik, deyim yerindeyse bir zihniyete dönüşmüştür. Jöntürk Hareketi’nin en radikal reformcuları bile, örneğin Ahmet Rıza ve Prens Sabahattin gibi farklı düşünce sistemlerine dahil olsalar ve politik çekişme içinde bulunsalar da, 1900'lü yılların başlarına kadar geleneksel fikirlerden kopamadıklarından, toplumsal gelişmenin ön şartı olarak maarifi görmeye devam etmişlerdir.

Maarifçi zihniyetin ilgi çekici tarafı, eğitimle ekonomik ve toplumsal gelişme arasında kurduğu ilişkinin ters dönmüş olarak baş aşağı durmasıdır. Osmanlı geleneksel yönetici sınıfıyla beraber bir bütün olarak aydınlar, eğitim olmadan hiçbir şey yapılamayacağı ve medeniyetin tesis edilemeyeceğini düşünürlerken, Batı'daki burjuva sınıfının ve onun medeniyetinin, ekonomik gelişmenin bir sonucu olduğunu görememektedirler. Öyle ki, Prens Sabahattin gibi kimi aydınlar işi eğitimle bir burjuva sınıfı yaratılabileceğine kadar götürebilmişlerdir. Halbuki kurulan ilişkinin sakatlığını gösteren işaretler de yok değildir. Özellikle sanat öğretmek ve sanayi çalışanı yetiştirmek için açılan okulların başarısız olması ve kapanması bile maarifçi zihniyetten kuşku duyulmasına yol açmamıştır.

Bu ilişkiyi düzelten olgu ise, Jöntürk Hareketi'nin Osmanlı burjuva sınıfiyla ilişki içerisine girerek onun organik bir parçası haline gelmesidir. Bu noktadan sonra, Osmanlı geleneksel hâkim sınıfı ve onun düşünceleriyle tüm bağlarını koparan Jöntürkler, iktisadiyatçı bir anlayış ile toplumsal gelişmeyi bir düzen sorunu olarak kavramışlardır. 


\section{KAYNAKÇA}

Akyüz Y. (2015). Türk Eğitim Tarihi. Ankara 2015.

Berkes N. (2003). Türkiye'de Çağdaşlaşma. İstanbul 2003.

Cevdet Paşa A. (2008).Osmanlı İmparatorluğu Tarihi. 2. Cilt. İstanbul 2008.

Coşkun A. (2006). 1895-1898 Yılları Arasında Yayınlanan Meşveret Gazetesinin Transkript ve Değerlendirilmesi. Yayımlanmamış Yüksek Lisans Tezi. Erciyes Üniversitesi, Sosyal Bilimler Ensititüsü, Kayseri 2006.

Çavdar T. (1992). Türkiye'de Liberalizm. Ankara 1992.

Faroqhi S. (2004). "Krizler ve Değişim”. Der. H. İnalcık \& D. Quataert. Osmanlı İmparatorluğunun Ekonomik ve Sosyal Tarihi (2004) 543-867. İstanbul.

Georgeon F. (2006). Abdülhamit. İstanbul 2006.

Göçek F. M. (1999). Burjuvazinin Yükselişi, İmparatorluğun Çöküşü. Ankara 1999.

Hanioğlu Ş. (1985). Bir Siyasal Örgüt Olarak Osmanlı 'Osmanlı Itttihat ve Terakki Cemiyeti' ve Jöntürkler. İstanbul 1985.

İnalcık H. (2003). Osmanlı İmparatorluğu Klasik Çă̆ (1300-1600). İstanbul 2003.

İnalcık H. (2006). “Tanzimat Nedir?”. Der. H. İnalcık \& M. Seyiddanlığlu. Tanzimat Değişim Sürecinde Osmanlı İmparatorluğu (2006) 29-57. İstanbul.

Jorga N. (2005). Osmanlı Imparatorluğu Tarihi Cilt 5. İstanbul 2005.

Kuran A. B. (1945). Inkilâp Tarihimiz ve Jöntürkler. İstanbul 1945.

Kuran A. B. (1956). Osmanlı İmparatorluğunda İnkllâp Hareketleri ve Millî Mücadele. İstanbul 1956.

Lewis B. (2000). Modern Türkiye'nin Doğuşu. Ankara 2000.

Mardin Ş. (1998). Yeni Osmanlı Düşüncesinin Doğuşu. İstanbul 1998.

Mardin Ş. (2000a). Türk Modernleşmesi. İstanbul 2000.

Mardin Ş. (2000b). Jöntürklerin Siyasî Fikirleri. İstanbul 2000.

Namık Kemal (2005). Maarif. Namık Kemal. Der. N. Y. Aydoğdu \& İ. Kara. İstanbul 2005.

Ortaylı İ. (2006a). Imparatorluğun En Uzun Yüzyıll. İstanbul 2006.

Ortaylı İ. (2006b). "Tanzimat Adamı ve Tanzimat Toplumu”. Der. H. İnalcık \& M. Seyiddanlığlu. Tanzimat Değişim Sürecinde Osmanlı İmparatorluğu (2006) 421-463. İstanbul.

Pamuk Ş. (2005). Osmanll-Türkiye İktisadi Tarihi 1500-1914. İstanbul 2005.

Petrosyan Y. A. (1974). Sovyet Gözüyle Jöntürkler. Ankara 1974.

Prens Sabahattin (1965). Bu Memleket Nasll Kurtarllabilir. İstanbul 1965.

Quataert D. (2004). “19. Yüzyıla Genel Bakış: Islahatlar Devri 1812-1914”. Der. H. İnalcık \& D. Quataert. Osmanlı İmparatorluğunun Ekonomik ve Sosyal Tarihi, Cilt 2 (2004) 885-1083 İstanbul.

Reyhan C. (2008). Osmanlı'da Kapitalizmin Kökenleri. İstanbul 2008.

“Tanzimat Fermanı” (2006). Der. H. İnalcık \& M. Seyiddanlığlu. Tanzimat Değişim Sürecinde Osmanlı Imparatorluğu (2006) 11-17. İstanbul.

Tekeli İ. \& İlkin S. (2003). “İttihat ve Terakki Hareketinin Oluşumunda Selânik'in Toplumsal Yapısının Belirleyiciliği”. Cumhuriyetin Harcı: Modernitenin Altyapısı Oluşurken (2003) 1-67. İstanbul.

Tekeli İ. (1993). “Osmanlı İmparatorluğu'ndan Günümüze Eğitim Kurumlarının Gelişimi”. Cumhuriyet Dönemi Türkiye Ansiklopedisi. 3. Cilt. İstanbul 1993.

Temo İ. (2000). Ittihad ve Terakki Anıları. İstanbul 2000.

Toprak Z. (1992). “Ikktisat Tarihi”. Der. M. Kunt \& S. Akşin. Türkiye Tarihi, Osmanlı Devleti 1600-1908, Cilt 3 (1992) 191-242. İstanbul.

Troçki L. (1995). Balkan Savaşları. İstanbul 1995.

Tunaya T. Z. (2004). Türkiye’nin Siyasî Hayatında Batılılaşma Hareketleri. İstanbul 2004. 